\title{
土壤污染予測のための広濃度範囲での 共存物影響を考慮した金属カチオン交換等温線
}

\author{
亀屋隆志 ${ }^{1} \cdot$ 大橋優子 $^{2} \cdot$ 小林剛 $^{3} \cdot$ 浦野紘平 $^{4}$ \\ ${ }^{1}$ 正会員 工博 横浜国立大学助教授 大学院工学研究院（２40-8501 横浜市保土ヶ谷区常盤台79-5） \\ E-mail: kameya@ynu.ac.jp \\ ${ }^{2}$ 工修 横浜国立大学大学院 工学研究科 ( T240-8501 横浜市保土ヶ谷区常盤台79-5) \\ 3 工博 横浜国立大学助手 大学院工学研究院（テ240-8501 横浜市保土ヶ谷区常盤台79-5） \\ ${ }^{4}$ 工博 横浜国立大学教授 大学院環境情報研究院（テ240-8501 横浜市保土ケ谷区常盤台79-7）
}

\begin{abstract}
本研究では, 有害金属類による土壤污染地域での污染物質の移動や污染範囲の予測を行う際に，各污染 レベルでの物質収支に基づいた解析を行えるようにするため, 各種土壌について $3 \sim 4$ 桁の広範囲の污染 濃度レベルにおける多成分系での有害金属カチオンの交換量の解析を行った. 高濃度域では有害金属カチ オンの交換量が土壤ごとに一定值で最大となり，また，土袞環境基準值付近の低濃度域では等温線が両対 数でほぼ直線となることが明らかになった.このときの直線の傾きを表すカチオン交換等温式の定数 $\mathrm{n} は$ ， 異なる土壤間においても有害金属力チオンごとにほぼ同じ值になるものとみなせた．また，有害金属力チ オンの交換量に大きく影響する土㙥中の $\mathrm{pH}$ とアルミニウムイオン濃度の影響を定量的に解析できた.
\end{abstract}

Key Words : soil contamination, toxic metal, cation -exchange isotherm, coexistent

1.はじめに

近年，土壤污染対策法の整備や ISO14000 の取得 等の自主的管理に伴い，土地再開発地域や事業所敷 地内での有害金属による土壤污染が顕在化しており， 国内での潜在的な污染地点は数干ヶ所に達すると推 定されている ${ }^{1)}$.これらは，高濃度の有害金属廃液 の漏洩，あるいは有害金属を含有する固体廃棄物の 放置や埋め立て，污染土㙵埋め戻し等によって引 き起こされ，雨水の浸透によって地中に拡大する. その結果, \%オーダーの高濃度の低 $\mathrm{pH}$ 有害金属廃 液で污染された土壤から ppm オーダーの土㙥環境 基準值レベルで污染された土墒まで，污染レベルが 極めて広い濃度範囲に及んでいるものと考えられる。

污染土壌の的確な調查や効率的な浄化を行うため には，有害金属の土壌中における挙動をあらかじめ 推定しておくことが必要となる．浸透した雨水に溶 解した有害金属カチオンは，イオン交換や沈殿，拡 散等をくり返しながら移動し，土壤污染の拡大を引
き起こすと考えられるが，特に，カチオンとなる有 害金属の挙動は土畩へのカチオン交換量によって大 きく異なる.このため, 従来から Freundlich 式 ${ }^{2) ~ 14) ~}$

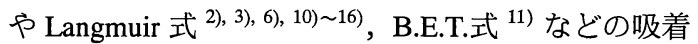
等温式を用いて，一定温度での土㙵間隙水中のカチ オン濃度と土壤へのカチオン吸着量との関係である カチオン交換等温式が検討されている.しかし，い ずれの等温式も適用できる濃度範囲が狭く限られて おり，また，実際には土壤ごとに大きく異なる共存 物の影響がほとんど考慮されていない.さらに,様々 な污染地の各種の土壤における幅広い污染条件につ いて一般化されたカチオン交換等温式は明らかにさ れていない。また, 有害金属カチオンの土壤への吸 着量は $\mathrm{pH}$ の低下, すなわち, 水素イオン濃度の上 昇によって滅少するほか, 土袞中にはカルシウムゃ マグネシウム, アルミニウムなどのカチオンが共存 しており，特に酸性になるとこれらが大量に間隙水 中へ溶出して, 有害金属カチオンの土壤への吸着を 妨害するものと考えられる. 特に，土壤環境基準值 
付近の低濃度の污染土壌においては，共存物や土壤 $\mathrm{pH}$ の影響を強く受けると考えられ, 土壤への吸着量 の詳細な評価が必要になると考えられる．しかし， 様々な土壌において低濃度の有害金属カチオンの土 袞への吸着量に影響する土㙵中の共存カチオンの影 響を詳細に検討した研究は少ない ${ }^{4)}$, 5), 8), 13), 17) ～19). このため, 土㙵污染実態の把握に不可欠な污染物質 の移動の予測や污染範囲の推定を行う際に必要な土 壤への吸着量を定量的に解析するための情報が不足 している.すなわち，従来から汎用されている移動 予測モデルでは, 土㙵への吸着容量と移動速度の両 者の影響を遅延係数としてまとめて考慮しており， 幅広い濃度範囲での詳細な物質収支の解析が難しい 状況にある.したがって, 土㙵への吸着量や移動速 度を゙それぞれ定量的に解析できれば，土㙵中での濃 度変化を伴う物質移動や物質収支をより正確に推定 できるようになり，土壌污染の広がりをより定量的 に把握できるようになると考えられる.

そこで本研究では, 土壌分類の異なる 4 種類の土 猿を，国内の地域の異なる合計 8 地点から採取し， 人あるいは水生生物に対する毒性 ${ }^{20)}$ が懸念され国 内使用量も多い 5 種類の有害金属カチオン $\left(\mathrm{Pb}^{2+}\right.$, $\left.\mathrm{Cd}^{2+}, \mathrm{Zn}^{2+}, \mathrm{Cu}^{2+}, \mathrm{Ni}^{2+}\right)$ について, 様々な濃度条件 および共存物条件において水一土壌間でのカチオン 交換等温式の解析を行い, 各種金属カチオンや各種 土袞の種類による土壌への吸着量の違いを定量的に 明らかにすることを目的とした。

\section{2. 実験}

\section{（1）対象金属}

本研究では, 人や水生生物に対する毒性が強く,
また, 国内使用量も比較的大きく, 雨水に溶解して カチオンになり地中を移動すると考えられる鉛 $(\mathrm{Pb})$, カドミウム $(\mathrm{Cd})$, 亜鉛 $(\mathrm{Zn})$, 銅 $(\mathrm{Cu})$, ニッケル $(\mathrm{Ni}) の$ 5 種類を対象とした.これら金属は, 関東化学(株) 社製の硝酸塩 $\mathrm{Pb}\left(\mathrm{NO}_{3}\right)_{2}, \mathrm{Cd}\left(\mathrm{NO}_{3}\right)_{2} \cdot 4 \mathrm{H}_{2} \mathrm{O}, \mathrm{Zn}\left(\mathrm{NO}_{3}\right)_{2}$ ・ $6 \mathrm{H}_{2} \mathrm{O}, \mathrm{Cu}\left(\mathrm{NO}_{3}\right)_{2} \cdot 3 \mathrm{H}_{2} \mathrm{O}, \mathrm{Ni}\left(\mathrm{NO}_{3}\right)_{2} \cdot 6 \mathrm{H}_{2} \mathrm{O}$ の特級試薬 をイオン交換水に溶かして実験に供した. なお, 共 存物の影響を調べる実験では, 同じく関東化学(株) 社製の硝酸塩 $\mathrm{Mg}\left(\mathrm{NO}_{3}\right)_{2} \cdot 6 \mathrm{H}_{2} \mathrm{O}, \mathrm{Ca}\left(\mathrm{NO}_{3}\right)_{2} \cdot 4 \mathrm{H}_{2} \mathrm{O}$, $\mathrm{Al}\left(\mathrm{NO}_{3}\right)_{3} \cdot 9 \mathrm{H}_{2} \mathrm{O}$ の特級試薬をイオン交換水に溶かし て所定濃度となるよう添加して用いた。

\section{(2) 対象土壤}

土袞の種類による有害金属カチオンの吸着量の違 いを明らかにするため, 日本国内で広く分布する黒 ボク土, 褐色森林土, 灰色台地土および陸成未熟土 の 4 種類について, 大きく地域の異なる合計 8 地点 から採取した土壌を用いた. 本研究で用いた土壌の 種類と特徵 ${ }^{21)}$ を表-1 に示す. 有機炭素含有率が $0.034 \% \sim 14 \%$, 比表面積も $1.8 \times 10^{3} \mathrm{~m}^{2} \cdot \mathrm{kg}$ - dry ${ }^{-1} \sim 6.2$ $\times 10^{4} \mathrm{~m}^{2} \cdot \mathrm{kg}$-dry ${ }^{-1}$ と非常に大きく異なった. また, 他 の地域から搬入された盛土や落ち葉等の未分解物を 大量に含む土壤を避けるため，できるだけ地層が見 える場所で, 表層から少なくとも数十 $\mathrm{cm}$ より深い 部分の土㗒を採取した. 採取した土壌は，大きな二 次粒子を乳鉢で粉砕して $2 \mathrm{~mm}$ 以下に篩い，日本土 壤肥料学会「土壌標準分析・測定法」 ${ }^{22)}$ の方法に準 拠し, 含水率が大きく変化しないように直射日光を 避けて 1〜2 日間風乾した後, ビニール袋に入れて常 温で密封保存した. 保存した土壌を実験に供する際 には，一部を取り出して含水率を測定することによ り湿潤重量ベースで科量して用い, 乾燥土壌量に換 算して解析することにした。

表-1 本研究で用いた土壌の種類と特徴

\begin{tabular}{|c|c|c|c|c|c|c|c|c|}
\hline 土袞名 & 採取地 & 種類 & 土袞の色 & $\begin{array}{c}\text { 採取した深さ } \\
{[\mathrm{m}]}\end{array}$ & $\begin{array}{c}\text { カチオン交換容量 } \mathrm{CEC}^{*}{ }^{\prime} \\
{\left[\mathrm{meq} \cdot \mathrm{kg}-\mathrm{dry}^{-1}\right]}\end{array}$ & $\begin{array}{c}\text { 比表面積 }^{* *)} \\
{\left[\mathrm{m}^{2} \cdot \mathrm{kg}^{\left.-\mathrm{dry}^{-1}\right]}\right.}\end{array}$ & $\begin{array}{c}\text { 有機炭素含有率 }^{* * * *)} \\
{[\%]} \\
\end{array}$ & $\begin{array}{l}\left.\mathrm{pH}^{*}\right) \\
{[-]}\end{array}$ \\
\hline Y1 & 横沂 & \multirow{4}{*}{ 黒ボク土 } & 黒 & 1 & 370 & $4.0 \times 10^{4}$ & 14 & 6.1 \\
\hline $\mathrm{Y} 2$ & 侽供 & & こげ茶 & 15 & 210 & $1.8 \times 10^{5}$ & 1.2 & 7.5 \\
\hline $\mathrm{K} 1$ & \multirow{2}{*}{ 熊本 } & & 黒 & 2 & 310 & $2.6 \times 10^{5}$ & 5.9 & 5.6 \\
\hline $\mathrm{K} 2$ & & & こげ茶 & 2 & 450 & $3.3 \times 10^{4}$ & 0.62 & 6.2 \\
\hline $\mathrm{O} 1$ & \multirow{2}{*}{ 大分 } & \multirow{2}{*}{ 灰色台地土 } & 灰 & 20 & 80 & $1.4 \times 10^{4}$ & 0.083 & 7.0 \\
\hline $\mathrm{O} 2$ & & & 灰 & 13 & 130 & $1.2 \times 10^{4}$ & 0.10 & 6.8 \\
\hline A & 秋田 & 褐色森林土 & 赤褐 & 1 & 190 & $6.2 \times 10^{4}$ & 0.59 & 4.8 \\
\hline $\mathrm{H}$ & 広島 & 陸成末熟土 & 黄 & 5 & 30 & $1.5 \times 10^{4}$ & 0.034 & 6.0 \\
\hline
\end{tabular}

$\left.{ }^{*}\right)$ 日本土壌肥料学会「土袞標準分析・測定法」 ${ }^{22}$ の方法に準拠した.

**) 窒素吸着法におけるB.E.T表面積を測定した(ユアサアイオニクス社製NOVA1200).

***) 燃焼酸化物を熱伝導度検出器で測定した(FISONS Instruments 社製EA-1108). 


\section{（3）溶出試験}

採取した土袞に含まれる共存カチオンを調べるた め, カチオン交換平衡実験の条件範囲内で共存カチ オンが最も溶出しやすい $\mathrm{pH} 4$ で溶出試験を行った. $300 \mathrm{~mL}$ 三角フラスコに $\mathrm{pH} 4$ の硝酸 $100 \mathrm{~mL}$ と湿潤土 壤 $10 \mathrm{~g}$-wet を入れて液固比 $10 \mathrm{~mL} \cdot \mathrm{g}^{-1}$ とし, $25^{\circ} \mathrm{C}$ の恒 温振とう器内で $80 \mathrm{spm}$ で $24 \mathrm{~h}$ 振とうした. 溶出が進 むにつれ $\mathrm{pH}$ が若干変化するので, 硝酸と水酸化ナ トリウム水溶液を用いて $\mathrm{pH}$ が 0.2 程度ずれるたびに $\mathrm{pH}$ 調整を行った。 $24 \mathrm{~h}$ 振とうにより $\mathrm{pH}$ 変動がほと んどみられなくなり，また，溶出が十分に平衡に達 したことを確認し, 溶出液を $5,000 \mathrm{rpm}$ で $15 \mathrm{~min}$ 遠心 分離した後, $0.5 \mu \mathrm{m}$ ガラス繊維ろ紙（東洋濾紙 GC-50）でろ過して，ろ液中の有害金属カチオン濃 度を高周波誘導プラズマ発光分析装置 (ICP-AES， Jobin-Yvon，JY 138 ULTRACE）で分析した。

\section{（4）回分カチオン交換平衡試験}

不均一な土壤を再現性良く採取するため $0.2 \mathrm{~g}$-wet 以上の所定量の湿潤土壌を秤りとり, 硝酸または水 酸化ナトリウム溶液で $\mathrm{pH} 4 ， 5 ， 6$ に調整した有害金 属・半金属溶液を $5 \sim 2000 \mathrm{~mL} \cdot \mathrm{g}^{-1}$ の範囲の液固比に なるように入れ, $25^{\circ} \mathrm{C}$ の恒温振とう器で $80 \mathrm{spm}$ で $24 \mathrm{~h}$ 以上振とうした. この際, カチオン交換が進む につれて $\mathrm{pH}$ が若干変化するので, 硝酸あるいは水 酸化ナトリウム溶液を用いて所定の $\mathrm{pH}$ になるよう 調整を行った。予備実験において，24h で十分に力 チオン交換平衡に達することを確認したので， $24 \mathrm{~h}$ 以上振とうした溶液を $5000 \mathrm{rpm}$ で $15 \mathrm{~min}$ 遠心分離し た上澄み液を $0.5 \mu \mathrm{m}$ ガラス繊維ろ紙（東洋濾紙 GC-50）を用いてろ過し，ろ液中の有害金属力チオ ン濃度を ICP-AES で分析した. 平衡時のカチオン交 換量 $\mathrm{Q}_{1}\left[\mathrm{meq} \cdot \mathrm{kg}\right.$-dry $\left.{ }^{-1}\right]$ は式 (1) で求めた.

$$
\mathrm{Q}_{1}=\frac{\left(\mathrm{C}_{0}-\mathrm{C}_{1}\right) \cdot \mathrm{V}}{\mathrm{W} \cdot(1-\alpha)}
$$

$\mathrm{C}_{0}\left[\mathrm{meq} \cdot \mathrm{L}^{-1}\right]$ : 初期の有害金属力チオン濃度 $\mathrm{C}_{1}\left[\mathrm{meq} \cdot \mathrm{L}^{-1}\right]$ : 平衡時の有害金属カチオン濃度 $\mathrm{V}[\mathrm{L}]:$ 溶液量

W[kg-wet] : 湿潤土壌重量

$$
\alpha\left[1-\mathrm{kg} \text {-dry } \cdot \mathrm{kg} \text { - } \text { wet }^{-1}\right] \text { : 含水率 }
$$

\section{（5）カチオン交換等温式}

土壤金属污染解析に用いる有害金属カチオン交換 等温式は，(1)高濃度有害金属廃液および溶出基準レ ベルの濃度でのカチオン交換量が表現できること， (2)共存物質の影響を定量的に表現できることが必要
である.そこで本研究では, キレート樹脂への有害 金属力チオンの競争吸着によく適合することが知ら れている式（2） ${ }^{23)}$ について，性状の異なる様々な 土㙵に対して広い濃度範囲で成り立つか否かを実験 的に検討することとした。

$$
\mathrm{Q}_{1}=\frac{\mathrm{Q}_{\max }}{1+\sum_{\mathrm{k}=2}^{\infty}\left(\frac{\mathrm{C}_{\mathrm{k}}^{\mathrm{n}_{\mathrm{k}}}}{\mathrm{K}_{\mathrm{k}}^{1}}\right) \cdot \frac{1}{\mathrm{C}_{1}^{\mathrm{n}_{1}}}}
$$

$\mathrm{Q}_{1}\left[\mathrm{meq} \cdot \mathrm{kg}-\mathrm{dry}^{-1}\right]$ は濃度 $\mathrm{C}_{1}$ における目的とする有害 金属カチオンの平衡交換量であり, $\mathrm{C}_{1}\left[\mathrm{meq} \cdot \mathrm{L}^{-1}\right]$ は有 害金属力チオンの平衡濃度, $\mathrm{C}_{\mathrm{k}}\left[\mathrm{meq} \cdot \mathrm{L}^{-1}\right]$ は共存力チ オン $\mathrm{k}$ の平衡濃度である. $\mathrm{n}_{1}[-]$ と $\mathrm{n}_{\mathrm{k}}[-]$ は有害金属 カチオンおよび共存カチオン $\mathrm{k}$ それぞれのカチオン 交換等温式の定数, $\mathrm{K}_{\mathrm{k}}^{1}\left[\left(\mathrm{meq} \cdot \mathrm{L}^{-1}\right)^{\mathrm{n}_{\mathrm{k}} \mathrm{n}_{1}}\right]$ は有害金属 カチオンと共存カチオンとの間の選択係数である.

$\mathrm{Q}_{\max }\left[\mathrm{meq} \cdot \mathrm{kg}-\mathrm{dry}^{-1}\right]$ は最大力チオン交換容量であり, 土壌ごとの物性值であるカチオン交換容量 $\mathrm{CEC}\left[\mathrm{meq} \cdot \mathrm{kg}^{-1}\right]$ に等しいものと考えられる.また， 式 (2) から明らかなように， $\mathrm{C}_{1}$ が十分大きい場合 には， $\mathrm{Q}_{1}$ は $\mathrm{Q}_{\max }$ に漸近する．逆に， $\mathrm{C}_{1}$ が十分小さ い場合には，式（2）は式（3）のような Freundlich 型の式で近似できる．すなわち，有害金属カチオン が低濃度の場合には, 平衡交換量 $\mathrm{Q}_{1}$ と平衡濃度 $\mathrm{C}_{1}$ との関係が，設定した共存物質の各濃度ごとに両対 数で直線近似できることになる.

$$
\mathrm{Q}_{1}=\mathrm{Q}_{\max } \cdot \sum_{\mathrm{k}=2}^{\infty}\left(\frac{\mathrm{K}_{\mathrm{k}}^{1}}{\mathrm{C}_{\mathrm{k}}^{\mathrm{n}_{\mathrm{k}}}}\right) \cdot \mathrm{C}_{1}^{\mathrm{n}_{1}}
$$

\section{3. 結果と考察}

\section{（1）広濃度範囲でのカチオン交換等温式の適 用性}

まず，最大カチオン交換容量 $\mathrm{Q}_{\max }\left[\mathrm{meq} \cdot \mathrm{kg}^{-1}\right]$ が有 害金属カチオンの違いや $\mathrm{pH}$ 条件によらず各土壌の 物性值として, $\mathrm{pH} 7$ の $1 \mathrm{M}$-酶酸アンモニウム溶液を 用いて求めることにより定義されているカチオン交 換容量 $\mathrm{CEC}\left[\mathrm{meq} \cdot \mathrm{kg}^{-1}\right]^{22)}$ と等しくなることを確かめ るため,黒ボク土Y1および陸成未熟土Hに対して， 吸着性の大きく異なる $\mathrm{Pb}^{2+}$ および $\mathrm{Cd}^{2+}$ の高濃度域に ついての等温線を $\mathrm{pH} 4$ および $\mathrm{pH} 6$ で調べた例を図-1 および図-2に示す. $\mathrm{Pb}^{2+}$ および $\mathrm{Cd}^{2+}$ の交換量は，平 衡濃度が高くなるにつれて大きくなったが, 次第に 頭打ちになり，それぞれのカチオンの最大交換量 $\mathrm{Q}_{\max }$ は各土壌ごとに等しいことがわかった。このこ とは，黒ボク土 $\mathrm{Y} 1$ および陸成末熟土 $\mathrm{H}$ のほか，本 
研究で用いた他の黒ボク土や褐色森林土, 灰色台地 土についても同様の結果となった. また, $\mathrm{pH}$ が異な る場合にも $\mathrm{Q}_{\max }$ はそれぞれの土壤ごとに一定であ った.このときの $\mathrm{Q}_{\max }$ の值は, $\mathrm{CEC}$ と同じ值になる ことが確かめられた.このため, $\mathrm{Pb}^{2+} や \mathrm{Cu}^{2+}$ などの 有害金属カチオンが土壌に保持される主たるメカニ ズムはイオン交換反応であると考えられた。

次に，8 ケ所から採取した各土壇に対する各有害 金属力チオンの低濃度域での等温線を $\mathrm{pH} 4$ の一定条 件で調べた結果を $\mathrm{Cd}^{2+}$ の例として図-3に示す.その 結果, 平衡濃度 $\mathrm{C}_{\mathrm{Cd}}$ と平衡交換量 $\mathrm{Q}_{\mathrm{Cd}}$ との関係は, いずれの土壌についても土㙥環境基準値付近の低濃 度域では, 両対数グラフで直線近似でき, $\mathrm{pH}$ 一定の 条件下で式（3）が成り立つことが確かめられた.

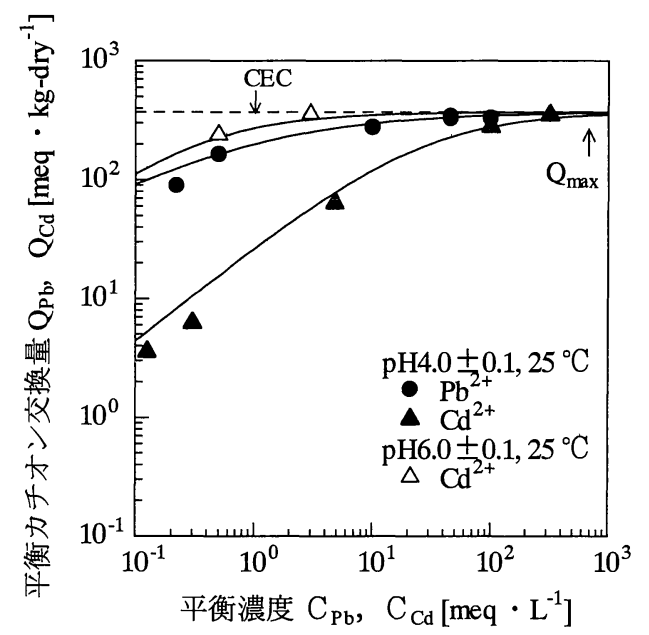

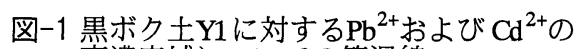
高濃度域についての等温線

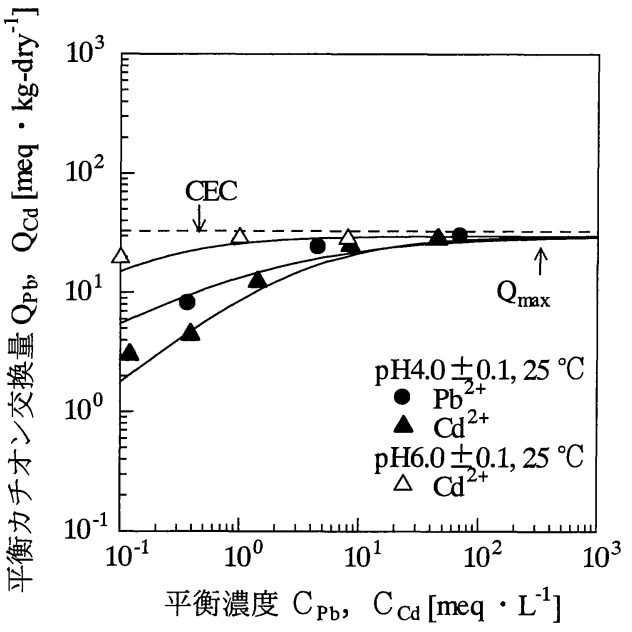

図-2 陸成末熟土Hに対する $\mathrm{Pb}^{2+}$ および $\mathrm{Cd}^{2+}$ の 高濃度域についての等温線

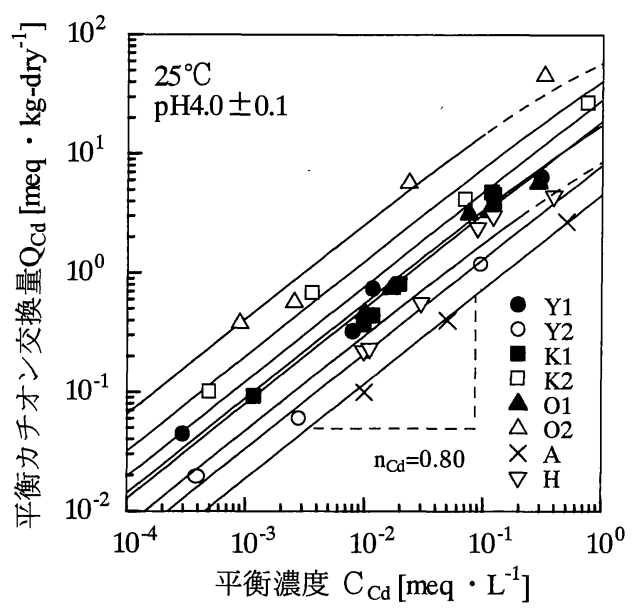

図-3 各土壌に対する $\mathrm{Cd}^{2+}$ の低濃度域での等温線

表-2 土袞の溶出試験結果

\begin{tabular}{|c|c|c|c|c|c|c|c|c|}
\hline \multirow{2}{*}{ カチオン名 } & \multicolumn{8}{|c|}{ 溶出濃度 $\left[\mathrm{meq} \cdot \mathrm{L}^{-1}\right]$} \\
\hline & Y1 & $\mathrm{Y} 2$ & $\mathrm{~K} 1$ & $\mathrm{~K} 2$ & O1 & $\mathrm{O} 2$ & A & $\mathrm{H}$ \\
\hline $\mathrm{Na}^{+}$ & 0.14 & 0.76 & 1.2 & 0.82 & 3.3 & 0.96 & 0.44 & 0.65 \\
\hline $\mathrm{Mg}^{2+}$ & 1.3 & 1.2 & 0.99 & 2.1 & 1.1 & 0.63 & 0.61 & 0.21 \\
\hline $\mathrm{Al}^{3+}$ & 1.2 & 0.031 & 0.052 & 0.040 & 0.058 & 0.047 & 0.44 & 0.022 \\
\hline $\mathrm{K}^{+}$ & 0.28 & - & - & - & - & - & - & - \\
\hline $\mathrm{Ca}^{2+}$ & 5.5 & 10 & 3.8 & 0.95 & 1.4 & 0.90 & 0.60 & 0.55 \\
\hline $\mathrm{Mn}^{2+}$ & 0.0073 & 0.0069 & 0.0073 & 0.0047 & 0.015 & 0.0013 & 0.040 & 0.0066 \\
\hline $\mathrm{Fe}^{2+}$ & 0.0014 & trace & trace & trace & 0.010 & 0.011 & 0.0028 & N.D \\
\hline $\mathrm{Zn}^{2+}$ & 0.0052 & 0.0052 & 0.0014 & 0.0034 & trace & 0.0070 & 0.0055 & 0.0043 \\
\hline $\mathrm{Sr}^{2+}$ & 0.022 & 0.027 & 0.025 & 0.010 & 0.0082 & 0.0050 & 0.0043 & 0.0052 \\
\hline $\mathrm{Ba}^{2+}$ & 0.019 & 0.013 & 0.025 & 0.014 & 0.020 & 0.014 & 0.0026 & 0.0051 \\
\hline
\end{tabular}


このとき, 両対数グラフの直線部分の傾きは, 土壤 の違いによらず一定とみなせたため, 式 (3) の $\mathrm{n}_{\mathrm{Cd}}$ 值はほぼ一定值で近似できると考えられた。このこ とは, $\mathrm{Cd}^{2+}$ 以外の $\mathrm{Pb}^{2+} や \mathrm{Zn}^{2+}, \mathrm{Cu}^{2+}, \mathrm{Ni}^{2+}$ についても 同様の実験結果が得られ, 式 ( 3 ) がいずれの有害 金属力チオンでも成り立つことが確かめられた.

\section{（2）共存カチオンの影響}

\section{a)土㙴中の共存カチオン}

土壤中にもともと含まれる共存カチオンの種類を 調べるために, カチオン交換平衡実験を行う条件の 範囲内で共存カチオンが最も溶出しやすいと考えら れる $\mathrm{pH} 4$ で溶出試験を行った結果を表-2に示す.い ずれの土壌からも,ナトリウム $\left(\mathrm{Na}^{+}\right)$やカリウム $\left(\mathrm{K}^{+}\right)$, マグネシウム $\left(\mathrm{Mg}^{2+}\right)$, カルシウム $\left(\mathrm{Ca}^{2+}\right)$, アルミニウ $厶\left(\mathrm{Al}^{3+}\right)$ というた交換性力チオンが, $\mathrm{Pb}^{2+}$ や $\mathrm{Cd}^{2+}$ など の有害金属力チオンの土䗙環境基準值(溶出基準值) に比べて 100 倍以上高い濃度で溶出することがわか り,これらの高濃度に溶出する共存カチオンが有害 金属カチオンの土壌への吸着量に与える影響を調べ る必要があると考えられた. 特に, 埋立地などでは $\mathrm{Ca}^{2+}$ が焼却灰から大量に溶出しているものと考えら れる ${ }^{24)}$. その他, 銀 $\left(\mathrm{Ag}^{+}\right)$や $\mathrm{Cd}^{2+}$, コバルト $\left(\mathrm{Co}^{2+}\right)$, クロム $\left(\mathrm{Cr}^{3+}\right), \mathrm{Cu}^{2+}, \mathrm{Ni}^{2+}$ の溶出量は定量下限未満の 小さな値であった.

また, 今回は $\mathrm{pH} 4$ の溶出条件で行ったが, 予備実 験においては, $\mathrm{pH}$ の上昇に伴って共存カチオンの溶 出量が大きく変化した. これより, 水中の水素イオ ン $\left(\mathrm{H}^{+}\right)$濃度が $\mathrm{Na}^{+}$や $\mathrm{K}^{+}, \mathrm{Mg}^{2+}, \mathrm{Ca}^{2+}, \mathrm{Al}^{3+}$ などの交換 性カチオンの溶出と有害金属力チオンの交換に大き く影響するものと考えられた。

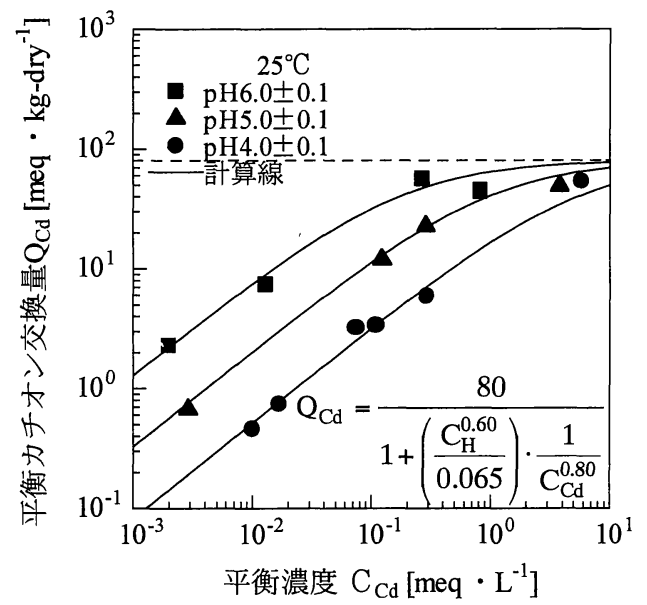

図-4 $\mathrm{H}^{+}$共存下での01に対する $\mathrm{Cd}^{2+}$ の交換等温線

\section{b）水素イオンの影響}

$\mathrm{H}^{+}$濃度は, $\mathrm{pH} 4$ で $0.1 \mathrm{meq} \cdot \mathrm{L}^{-1}, \mathrm{pH} 5$ で $0.01 \mathrm{meq} \cdot \mathrm{L}^{-1}$, $\mathrm{pH} 6$ で $0.001 \mathrm{meq} \cdot \mathrm{L}^{-1}$ であり, 有害金属カチオンの土 猿環境基準值（溶出基準値）を $\mathrm{meq} \cdot \mathrm{L}^{-1}$ 単位に換算 した濃度に比べると, pH6 で同程度, $\mathrm{pH} 4$ で約 100 倍の濃度の $\mathrm{H}^{+}$が共存していることになる.特に，土 壌污染の有無判定を行う土壌環境基準值（溶出基準 值）付近の低濃度域においては, pH によって有害金 属力チオンの交換量が大きく変化すると考えられた. このため, 本実験のすべての回分平衡実験は, 適宜 $\mathrm{pH}$ 調整を行いながら行った.用いた 8 種類の土壌に ついて, pH4, pH5, pH6での有害金属カチオンの低 濃度域の等温線を調べた結果を灰色台地土 01 と黒 ボク土 $\mathrm{K} 2$ に対する $\mathrm{Cd}^{2+}$ の例で図-4 および図-5に示 す. 土壤環境基準値（溶出基準值）付近の低濃度域 では, 平衡交換量 $\mathrm{Q}_{\mathrm{Cd}}$ と平衡濃度 $\mathrm{C}_{\mathrm{Cd}}$ との関係がい ずれの $\mathrm{pH}$ 条件下においても両対数グラフで直線近 似でき，また， $\mathrm{pH}$ 条件が異なる場合にも直線の傾き はほぼ同じになることが明らかになり，式（３）が 成り立つことが確かめられた。

また，両対数グラフの直線部分の傾きは，灰色台 地土 01 や黒ボク土 K2 以外の他の黒ボク土や褐色森 林土，陸成未熟土についてもほぼ同じとみなせ， 式（３）の $\mathrm{n}_{\mathrm{Cd}}$ 值は土壌の違いによらずほぼ一定值 として近似できるとことが明らかになった。また， $\mathrm{Cd}^{2+}$ 以外の $\mathrm{Pb}^{2+} や \mathrm{Zn}^{2+}, \mathrm{Cu}^{2+}, \mathrm{Ni}^{2+}$ についても同様の 実験結果が得られ，低濃度域での直線の傾きを表す $\mathrm{n}_{1}$ の值は, 土壌の種類によらず, 有害金属カチオン ごとにほぼ一定值として近似できることが確かめら れた。

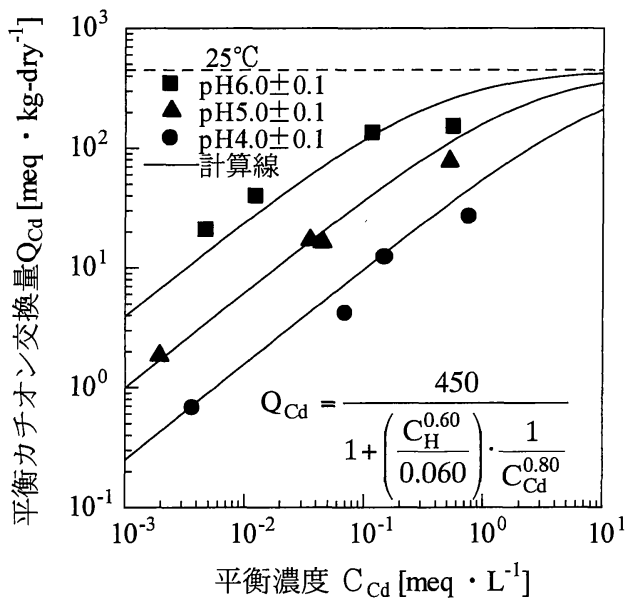

図-5 $\mathrm{H}^{+}$共存下でのK2に対する $\mathrm{Cd}^{2+}$ の交換等温線 
また，有害金属カチオンの交換量 $\mathrm{Q}_{1}$ に対する $\mathrm{H}^{+}$ の影響度を表す $\mathrm{n}_{\mathrm{H}}$ は, 各 $\mathrm{pH}$ 条件の実験で得られた $\mathrm{Q}_{1}, \mathrm{C}_{1}, \mathrm{C}_{\mathrm{H}}$ のデー夕を式 (2) や式 (3) に対して の重回帰分析を行うことにより求めることができる。 図-4 および図-5 のデータについて重回帰分析を行 ったところ, 式 (2) や式 (3) が有意差 1\%以下 で統計学的に有意であることが確かめられ， $\mathrm{n}_{\mathrm{H}}$ の值 は 0.60 でほぼ一致する結果となった.これより, $\mathrm{Cd}^{2+}$ の例では, $\mathrm{pH}$ の值が 1 だけ小さくなり, $\mathrm{H}^{+}$の濃度 が十倍大きくなるごとに，有害金属力チオンの交換 量は 4 分の 1 程度に低下していくことを定量的に明 らかにできた。

また，他の土壤や他の有害カチオンについても， 図-4 や図-5 と同様の実験結果が得られ, $\mathrm{n}_{\mathrm{H}}$ は, 有 害金属カチオンの $\mathrm{n}_{1}$ と同様に, 土㙵の種類や共存す る有害金属カチオンの種類によらない一定值として 近似できることが確かめられた.

以上により，従来 $\left.\left.\left.{ }^{4)}, 5\right), 8\right), 13\right), 17$ 19) は，限られた金 属や土猿についての限られた濃度範囲での影響が経 験的に把握されるのみであった土㙵への有害金属力 チオンのイオン交換量が, 式 (2) や式 (3) を用 いて, 幅広い濃度範囲の幅広い $\mathrm{pH}$ 条件の下で一般 化できるものと考えられた。

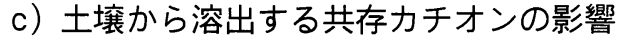

土壤から大量に溶出した $\mathrm{Na}^{+}, \mathrm{K}^{+}, \mathrm{Mg}^{2+}, \mathrm{Ca}^{2+}$, $\mathrm{Al}^{3+}$ のうち, アルカリ金属の $\mathrm{Na}^{+}$と $\mathrm{K}^{+}$は, イオン価 数が小さく，イオン化傾向が非常に大きいため, 溶 出した濃度レベルでは有害イオンに比べて交換力が 極めて小さいものと考えられたので,ここでは, $\mathrm{Al}^{3+}$, $\mathrm{Mg}^{2+}, \mathrm{Ca}^{2+}$ の共存影響を調べることとした。

まず, $\mathrm{Al}^{3+}$ の共存影響について, $\mathrm{Pb}^{2+}$ の $\mathrm{pH} 4$ での 黒ボク土 Y1 に対する等温線を調べた結果を図-6に

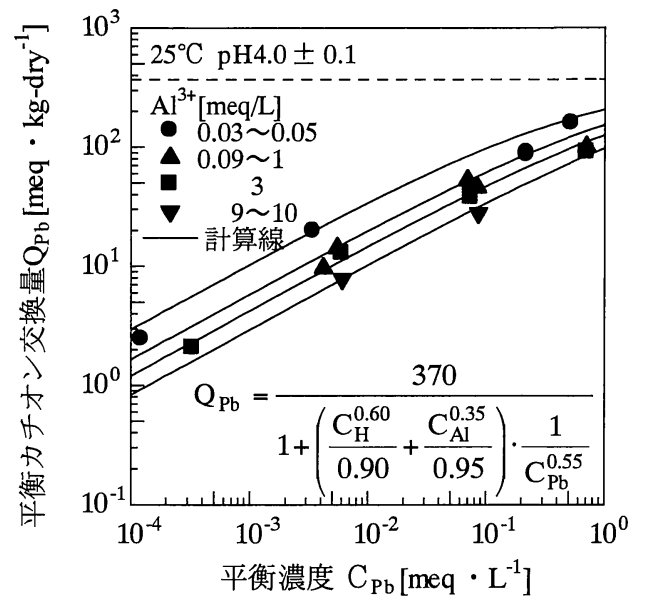

図-6 $\mathrm{Al}^{3+}$ と $\mathrm{H}^{+}$共存下でのY1に対する $\mathrm{Pb}^{2+}$ の 交換等温線
示す. 現害の土袞でも十分に起こりうる $0.01 \mathrm{meq} \cdot \mathrm{L}^{-1}$ $\sim 10 \mathrm{meq} \cdot \mathrm{L}^{-1}$ の範囲で共存させたところ, 他の有害 金属カチオンに比べて選択性が大きい $\mathrm{Pb}^{2+}$ の交換量 を明らかに低下させる場合があることが確認された。 特に, $\mathrm{Al}^{3+}$ の溶出量が大きい黒ボク土 $\mathrm{Y} 1$ では, 他の 土壤に比べて, $\mathrm{Pb}^{2+}$ の交換量が 6 分の 1 程度まで低 下することが示された。このとき， $\mathrm{Al}^{3+}$ の影響度を 表す $\mathrm{n}_{\mathrm{Al}}$ は， $\mathrm{H}^{+}$の影響度を表す $\mathrm{n}_{\mathrm{H}}$ の場合と同様に， 式 (2) を $\mathrm{Pb}^{2+}, \mathrm{H}^{+}, \mathrm{Al}^{3+}$ の 3 成分系について適用 した式を重回帰分析することによって求めることが できた。すなわち，まず， $\mathrm{Al}^{3+}$ がほとんど存在しな い状態で求めた $n_{\mathrm{Pb}}, \mathrm{n}_{\mathrm{H}}, \mathrm{K}_{\mathrm{H}}^{\mathrm{Pb}}$ を用いて, 図-6 から $\mathrm{Al}^{3+}$ 共存下での $\mathrm{C}_{\mathrm{Pb}}, \mathrm{Q}_{\mathrm{Pb}}$ の実験デ一夕を重回帰分析 することによって求めた.この $\mathrm{K}_{\mathrm{Al}}^{\mathrm{Pb}}$ の值は $0.95, \mathrm{n}_{\mathrm{Al}}$ の值は 0.35 でほぼ一致する結果となった. また, $\mathrm{n}_{\mathrm{Al}}$ の值は，他の有害金属カチオンに対する $\mathrm{Al}^{3+}$ の影響 の場合についてもほぼ同じ值とみなせた.すなわち， 目的とする有害金属力チオンの種類や土壤の種類, $\mathrm{pH}$ によらず一定值で近似できることが明らかにな った.

続いて, $\mathrm{Mg}^{2+}$ の共存影響について, $\mathrm{Ni}^{2+}$ の $\mathrm{pH} 4$ で の黒ボク土 Y1 に対する等温線を調べた結果を図-7 に示す. 実際の土壌から溶出する可能性が考えられ る範囲よりやや広めの $0.3 \mathrm{meq} \cdot \mathrm{L}^{-1} \sim 8.0 \mathrm{meq} \cdot \mathrm{L}^{-1}$ の $\mathrm{Mg}^{2+}$ を共存させたが，他の有害金属カチオンに比べ て選択性が小さい $\mathrm{Ni}^{2+}$ の交換に対しても, $\mathrm{Mg}^{2+}$ 共存 の影響はほとんどないことが確かめられ，他の土壤 についても同様の実験結果が得られた.

このほか, もともとの土袞からの溶出のほか, 焼 却灰埋立地等で大量に溶出してくる $\mathrm{Ca}^{2+}$ の共存影響 について, $\mathrm{Ni}^{2+}$ の $\mathrm{pH} 4$ での黒ボク土 $\mathrm{Y} 1$ に対する等 温線を調べた結果を図-8に示す. $\mathrm{Ca}^{2+}$ の溶解度は $\mathrm{pH}$

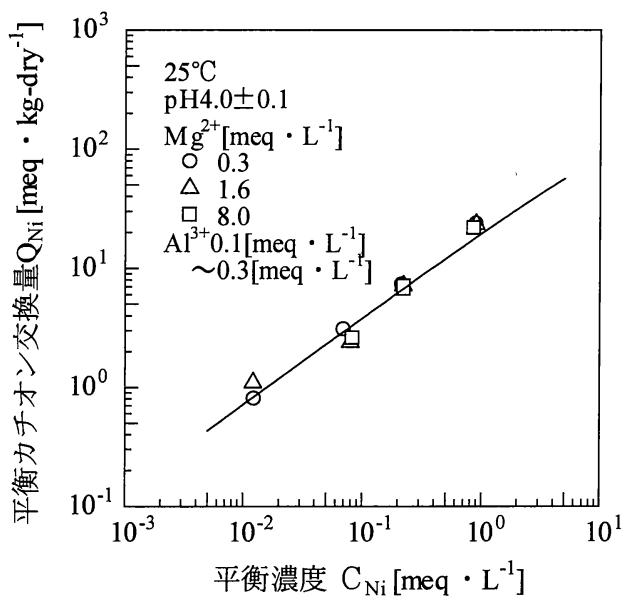

図-7 $\mathrm{Mg}^{2+}$ と $\mathrm{H}^{+}$共存下でのY1に対する $\mathrm{Ni}^{2+}$ の 交換等温線 
によっても異なるが，かなり過酷な共存条件として $500 \mathrm{meq} \cdot \mathrm{L}^{-1}$ まで共存させたが, 他の有害金属カチオ ンに比べて選択性の小さい $\mathrm{Ni}^{2+}$ 交換に対しても， $\mathrm{Ca}^{2+}$ 共存の影響はほとんどないことが確かめられた. また, $\mathrm{Mg}^{2+}$ を $8 \mathrm{meq} \cdot \mathrm{L}^{-1}$ まで共存させた条件でも， $\mathrm{Mg}^{2+}$ 共存の影響はほとんどないことが確かめられ， 他の土壌についても同様の実験結果が得られた.

以上より，土袞から溶出する共存カチオンの中で

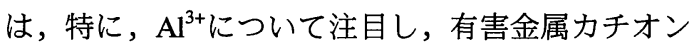
の交換量を求める前に溶出量を把握しておく必要が あることが明らかになった。

\section{（3）各有害カチオンの選択性}

土壤が複数の有害金属カチオンで污染されている 場合や， $\mathrm{Al}^{3+}$ の溶出量が大きい土壌については， 式（2）あるいは式（3）を $\mathrm{H}^{+}$を含めた 3 成分系で

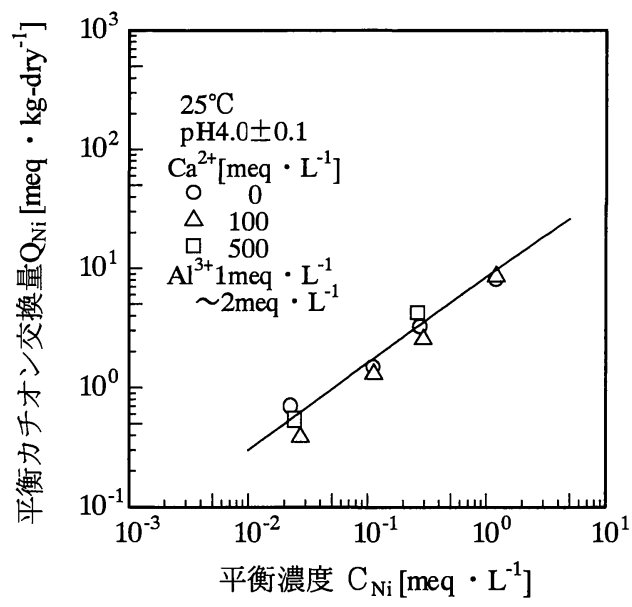

図-8 $\mathrm{Ca}^{2+}$ と $\mathrm{H}^{+}$共存下でのY1に対する $\mathrm{Ni}^{2+}$ の 交換等温線
適用する必要がある．このとき，選択係数の定義か らすれば, $\mathrm{H}^{+}$との 2 成分系で求めたそれぞれの選択 係数同士を除することにより, 有害金属カチオン同 士の選択係数は式 (4) によって計算で求めること ができる.

$$
\mathrm{K}_{2}^{1}=\mathrm{K}_{3}^{1} / \mathrm{K}_{3}^{2}
$$

そこで, 計算的に求めた選択係数が実測值と一致す るかどうかを確認することとした. $\mathrm{pH} 4$ 一定で $\mathrm{Pb}^{2+}$, $\mathrm{Cd}^{2+}$ 灰色台地土 $\mathrm{O} 1$ に添加することにより求めた $\mathrm{Cd}^{2+}$ の交換等温線を図-9に示す.これより, 式 (2) の 3 成分系等温式を直接に重回帰分析あるいはカー ブフィッティング解析することにより求めた $\mathrm{K}_{\mathrm{Cd}}^{\mathrm{Pb}}$ の 值は,あらかじめ $\mathrm{H}^{+}$と $\mathrm{Pb}^{2+}$ あいい $\mathrm{Cd}^{2+}$ の 2 成分系 で求めておいた $\mathrm{K}_{\mathrm{H}}^{\mathrm{Pb}}$ および $\mathrm{K}_{\mathrm{H}}^{\mathrm{Cd}}$ から式 (4) で計算 した $\mathrm{K}_{\mathrm{Cd}}^{\mathrm{Pb}}$ の値とほぼ一致することが確認できた.

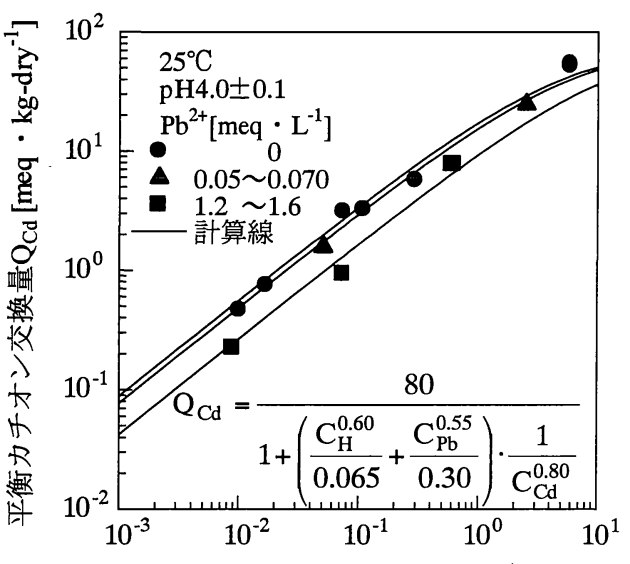

平衡濃度 $\mathrm{C}_{\mathrm{Cd}}\left[\mathrm{meq} \cdot \mathrm{L}^{-1}\right]$

図-9 $\mathrm{Pb}^{2+}$ と $\mathrm{H}^{+}$共存下での01に対する $\mathrm{Cd}^{2+}$ の 交換等温線

表-3 各種土壌への各種有害金属カチオンの交換等温式における指数と係数

\begin{tabular}{|c|c|c|c|c|c|c|c|c|c|}
\hline \multirow{2}{*}{ カチオン名 } & \multirow{2}{*}{ 定数と選択係数 } & \multicolumn{8}{|c|}{ 土壌名 } \\
\hline & & $\mathrm{Y} 1$ & $\mathrm{Y} 2$ & K1 & $\mathrm{K} 2$ & O1 & $\mathrm{O} 2$ & A & $\mathrm{H}$ \\
\hline \multirow{2}{*}{$\mathrm{Pb}$} & $\mathrm{n}_{\mathrm{Pb}}[-]$ & \multicolumn{8}{|c|}{0.55} \\
\hline & $\mathrm{K}_{\mathrm{H}}^{\mathrm{Pb}}\left[\left(\mathrm{meq} \cdot \mathrm{L}^{-1}\right)^{\mathrm{n}_{\mathrm{H}-\mathrm{nPb}}}\right]$ & 0.90 & 0.45 & 0.70 & 0.15 & 0.20 & 0.35 & 0.90 & 0.25 \\
\hline \multirow{2}{*}{$\mathrm{Cd}$} & $\mathrm{n}_{\mathrm{Cd}}[-]$ & \multicolumn{8}{|c|}{0.80} \\
\hline & $\mathbf{K}_{\mathrm{H}}^{\mathrm{Cd}}\left[\left(\mathrm{meq} \cdot \mathrm{L}^{-1}\right)^{\mathrm{n}_{\mathrm{H}}-\mathrm{n}_{\mathrm{Cd}}}\right]$ & 0.15 & 0.015 & 0.025 & 0.060 & 0.065 & 0.20 & 0.15 & 0.10 \\
\hline \multirow{2}{*}{$\mathrm{Zn}$} & $\mathrm{n}_{\mathrm{Zn}}[-]$ & \multicolumn{8}{|c|}{0.75} \\
\hline & $\mathrm{K}_{\mathrm{H}}^{\mathrm{Zn}}\left[\left(\mathrm{meq} \cdot \mathrm{L}^{-1}\right)^{\mathrm{n}_{\mathrm{H}}-\mathrm{n} \mathrm{Zn}}\right]$ & 0.15 & 0.015 & 0.010 & 0.015 & 0.035 & 0.030 & 0.015 & 0.050 \\
\hline \multirow{2}{*}{$\mathrm{Cu}$} & $\mathrm{n}_{\mathrm{Cu}}[-]$ & \multicolumn{8}{|c|}{0.70} \\
\hline & $\mathrm{K}_{\mathrm{H}}^{\mathrm{Cu}}\left[\left(\mathrm{meq}^{-} \cdot \mathrm{L}^{-1}\right)^{\mathrm{n}_{\mathrm{H}}-\mathrm{n}_{\mathrm{Cu}}}\right]$ & 0.90 & 0.10 & 0.25 & 0.050 & 0.25 & 0.15 & 0.050 & 0.25 \\
\hline \multirow{2}{*}{$\mathrm{Ni}$} & $\mathrm{n}_{\mathrm{Ni}}[-]$ & \multicolumn{8}{|c|}{0.85} \\
\hline & $\mathrm{K}_{\mathrm{H}}^{\mathrm{N}_{1}}\left[\left(\mathrm{meq} \cdot \mathrm{L}^{-1}\right)^{\mathrm{n}_{\mathrm{H}}-\mathrm{n}_{\mathrm{Ni}}}\right]$ & 0.95 & 0.015 & 0.060 & 0.030 & 0.035 & 0.65 & 0.50 & 0.30 \\
\hline $\mathrm{H}$ & $n_{H}[-]$ & \multicolumn{8}{|c|}{0.60} \\
\hline
\end{tabular}


これより, 目的とする有害カチオン以外の $\mathrm{H}^{+}$を含め た 2 成分の濃度を一定にしなければならない条件設 定が困難な 3 成分系の平衡実験を行うよりも，各土 壤ごとに各有害金属力チオンや $\mathrm{Al}^{3+}$ と $\mathrm{H}^{+}$との間の 選択係数 $\mathrm{K}_{\mathrm{H}}^{1}$ や $\mathrm{K}_{\mathrm{H}}^{\mathrm{Al}}$ ，および各カチオンについての 等温式の定数 $\mathrm{n}_{1}, \mathrm{n}_{\mathrm{H}}, \mathrm{n}_{\mathrm{Al}}$ を求めておけば, 複数の有 害金属カチオンで污染されている場合や， $\mathrm{Al}^{3+}$ の溶 出量が大きい土壌についての 3 成分系の解析が容易 に行えるものと考えられた。

\section{（4）各有害金属カチオンの各土壌における 等温式のパラメータ}

各有害金属力チオン, 各土袞について求めた交換 定数 $\mathrm{n}$, 選択係数 $\mathrm{K}_{\mathrm{H}}^{1}$ の結果を表-3に示す. 用いた 土袞は，有機炭素含有率が $0.034 \%$ 14\%，比表面積 も $1.8 \times 10^{3} \mathrm{~m}^{2} \cdot \mathrm{kg}$-dry ${ }^{-1} \sim 6.2 \times 10^{4} \mathrm{~m}^{2} \cdot \mathrm{kg}^{-\mathrm{dry}}{ }^{-1}$ と非常 に大きく異なったが，有害金属カチオンおよび共存 カチオン $\mathrm{k}$ それぞれの交換定数 $\mathrm{n}_{1}, \mathrm{n}_{\mathrm{k}}$ は, カチオン の種類によって決まることが明らかになった.また， $\mathrm{n}_{1}$ はカチオンの種類で決まる定数であるため, 有害 カチオンの物性であるイオン半径, 標準電極電位と 関係がないか調べたが， $\mathrm{n}_{1}$ はイオン半径や標準電極 電位と関係がないことがわかった. また, 最大力チ オン交換量 $\mathrm{Q}_{\max }$ は有害金属カチオンの種類によら ない各土袞の物性值であるカチオン交換容量 CEC として測定できるので, 各土埣について比較的少数 の実験によって選択係数 $\mathrm{K}_{\mathrm{H}}^{1}$ を求めるだけで, 有害 金属力チオンの交換等温線が予測できることになり， 多くの土壤金属污染地において, 幅広い濃度レベル にわたる污染物質の移動や污染の広がりの予測に活 用できると考えられた。

\section{4. 結論}

(1) 土㗒への有害金属カチオン交換平衡について, キレート樹脂吸着で用いられる多成分系カチオ ン交換等温式の適用を提案し, 幅広い濃度範囲で 適用可能なことを明らかにした。この等温式を用 いれば, \%オーダーの廃液が接触する表層付近な どの高濃度污染土壌から, 雨水により地中に広が つた土㙥環境基準值レベルの低濃度污染土壌ま での様々な污染レベルの評価や污染の移動解析 が定量的に行えると考えられた.

(2) 有害金属カチオンの土㙵への交換量は, $\mathrm{H}^{+} ゃ$ $\mathrm{Al}^{3+}$ が大量に共存する場合に大きく低減するこ とが明らかになり,様々な共存条件での交換量が 提案した等温式を用いて定量的に把握できるよ
うになった。

$$
\mathrm{Q}_{1}=\frac{\mathrm{Q}_{\max }}{1+\sum_{\mathrm{k}=2}^{\infty}\left(\frac{\mathrm{C}_{\mathrm{k}}^{\mathrm{k}}}{\mathrm{K}_{\mathrm{k}}^{1}}\right) \cdot \frac{1}{\mathrm{C}_{1}^{\mathrm{n}_{1}}}}
$$

(3) 提案した多成分系カチオン交換等温式は 2 成分 の複合污染にも適用可能なことが示された.

(4) 各種土壌について等温式の係数を求めたところ, 有害金属カチオンおよび共存カチオンの交換定 数 $\mathrm{n}_{1}, \mathrm{n}_{\mathrm{k}}$ は, 土袞の違いには関係なくカチオンそ れぞれによって定まる一定值とみなせた.これよ り, カチオン交換容量 $\mathrm{CEC}\left(=\mathrm{Q}_{\mathrm{max}}\right)$ と選択係数 $\mathrm{K}_{\mathrm{k}}^{1}$ のみを比較的少ない実験で求めることにより, 様々な土壤について有害金属力チオンの吸着量 が定量的に評価できると考えられた。

以上より, 各土袞中での $\mathrm{H}^{+} や \mathrm{Al}^{3+}$ を含めた共存 カチオンの存在量を調べ, これらの共存イオンの影 響を考慮した広い濃度範囲でのカチオン交換等温線 を用いることにより, 大きな濃度変化を伴う土㗒中 での移動における土袞および土㙵間隙水中でのカチ オン交換平衡が, 任意の濃度について定量的に把握 できるようになった. 今後さらに速度解析を行うこ とにより, 有害金属力チオンの土壤中移動の予測計 算が可能になるものと考えられた。

\section{参考文献}

1) 山本勇: 土壤・地下水污染と企業リスク, "土壌污染対 策法"と土壤・地下水保全の今後講演要旨集, pp.11-16, 2002.

2) Anghinoni, I., Baligar, V.C. and Wright, R.J.: Phosphorus sorption isotherm characteristics and availability parameters of appalachian acidic soils, Commun. Soil Sci., Plant Anal., 27, pp.2033-2048, 1996.

3) Atanassova, I. and Okazaki, M.: Adsorption-desorption characteristics of high levels of copper in soil clay fractions, Water, Air, and Soil Pollut., 98, pp.213-228, 1997.

4) Atenassova, I.: Competitive effect of copper, zinc, cadmium and nickel on ion adsorption and desorption by soil clays, Water, Air, and Soil Pollut., 113, pp.115-125, 1999.

5) Chen, C.T., Lee, D.Y. and Houng, K.H.: Competitive adsorption of $\mathrm{Cd}, \mathrm{Cu}$, and $\mathrm{Pb}$ by acid soils, J. Chin. Agric. Chem. Soc., 30, pp.83-99, 1992.

6) Houng, K. H. and Lee, D.Y.: Comparisons of linear and nonlinear langmuir and freundlich curve-fit in the study of $\mathrm{Cu}, \mathrm{Cd}$, and $\mathrm{Pb}$ adsorption on Taiwan soils, Soil Sci., 163, pp.115-121, 1998. 
7) Jarvis, S.C. and Jones, L.H.P: The contents and sorption of cadmium in some agricultural soils of England and Wales, Soil Sci., 31, pp.469-479, 1980.

8) Miragaya, J.G. and Page, A.L.: Sorption of trace quantities of cadmium by soils with different chemical and mineralogical composition, Water, Air, and Soil Pollut., 9, pp.289-299, 1978.

9) O'Connor, G.A., O'Connor, C. and Cline, G.R.: Sorption of cadmium by calcareous soils, Influence of solution composition, Soil. Sci. Soc. Am. J., 48, pp.1244-1247, 1984.

10) Ramachandran, V. D. and Souza, T.J.: Adsorption of cadmium by Indian soils, Water, Air, and Soil Pollut., 111, pp.225-234, 1999.

11) Taylor, R.W., Hassan, K., Mehadi, A. and Shuford, J.W.: Zinc sorption by some Alabama soils, Commun, Soil Sci. Plant Anal., 26, pp.993-1008, 1995.

12) Tsadilas, C.D., Samaras, V. and Dimoyiannis, D.: Phosphate sorption by red mediterranean soils from Greece. Commun, Soil Sci. Plant Anal., 27, pp.2279-2293, 1996.

13) Kinniburgh, D.G., W.H. van Riemsdijk, Koopal, L.K., Borkovec, M., Benedetti, M.F. and Avena, M.J.: Ion binding to natural organic matter: competition, heterogeneity, stoichometry and themodynamic consistency, Colloids and Surfs. A,-151, pp.147-166, 1999.

14) Harter, R.D.: Curve-fit errors in Langmuir Adsorption Maxima, Soil Sci. Soc. Am. J., 48, pp.749-752, 1984.

15) Singh, B. and Sekhon, G.S.: Adsorption, desorption and solubility relationships of lead and cadmium in some alkaline soils, Soil Sci., 28, pp.271-275, 1977.

16) Udo, E.J., Bohn, H.L. and Tuker, T.C.: Zinc adsorption by calcareous soils, Soil Sci. Soc. Am. Proc., 34, pp.405-407, 1970.

17) Christensen, T.H.: Cadmium soil sorption at low concentrations: V. Evidence of competition by other heavy metals, Water, Air, and Soil Pollut., 34, pp.293-303, 1987.

18) Harter, R.D.: Effect of soil pH on adsorption of lead, copper, zinc, and nickel, Soil Sci. Soc. Am. J., 47, pp.47-51, 1983.

19) Bruemmer, G.W., Gerth, J. and Tiller, K.G.: Reaction kinetics of the adsorption and desorption of nickel, zinc, and cadmum by goethite I. Adsorption and diffusion of metals, Soil Sci., 39, pp.37-52, 1988.

20) 大橋優子: 金属-半金属類の毒性, 化学物質と環境, 43, pp.1-3, 2000.

21）農耕地土㗒分類委員会: 農耕地土䁃分類第三次改訂 版，農業環境技術研究所資料, 17, 1995.

22）土壌標準分析·測定法委員会: 土壌標準分析・測定法, 博友社, pp.70-71, pp.150-154, 1994.

23) Urano, K., Koichi, Y. and Nakazawa, Y.: Adsorption isotherm equation of single heavy metal ion in acidic solution on chelating resin, J. Colloid Interface Sci., 82, pp.251-253, 1981.

24) 松藤康司, 島岡隆行: 浸出水流出特性と埋立地建設へ の課題, 廃棄物学会誌, 8, pp.510-522, 1997.

(2004.1.5 受付)

\title{
EXCHANGE ISOTHERM OF TOXIC METAL CATIONS ON SOILS IN CONSIDERATION OF COEXISTENCE IN WIDE CONCENTRATION RANGE FOR METAL CONTAMINATION SURVEY
}

\author{
Takashi KAMEYA, Yuko OHASHI, Takeshi KOBAYASHI and Kohei URANO
}

The cation-exchange equilibrium of toxic metal cations were investigated in wide concentration range to predict their behavior in contaminated soils. When the concentration of toxic metal cation in water was high enough, the exchange amount became saturation at the cation exchange capacity of each soil. The exchange isotherms in low concentration range showed the linear relation ship in $\log C_{1} v s . \log Q_{1}$ diagram with slope $n_{1}$. The value of $n_{1}$ was not based on the kind of soil, but was determined for each cation. The influence of coexisting cation was expressed quantitatively by the multiple isotherm equation proposed in this study. The concentrations of $\mathrm{H}^{+}$and $\mathrm{Al}^{3+}$ gave the strong effects to the exchange of toxic cations. 